\title{
Use of Complementary and Alternative Medicine Methods Among Elderly People Living in Nursing Homes
}

\author{
Huzurevinde Kalan Yașlılarda Tamamlayıcı ve Alternatif Tıp Yöntemlerini Kullanma Durumu
}

\author{
Zeynep Erdoğan', Ayșe Çil Akıncı' , Derya Emre Yavuz ${ }^{3}$, Zeynep Kurtuluș Tosun', Derya Atik ${ }^{\mathbf{5}}$ \\ ${ }^{1}$ Bülent Ecevit University, Ahmet Erdoğan Vocational School of Health Services, Zonguldak; ${ }^{2}$ Medeniyet University Faculty of Health \\ Sciences, Nursing Department; ${ }^{3}$ Marmara University Faculty of Health Sciences, Nursing Department, Istanbul; ${ }^{4}$ Namik Kemal \\ University, School of Health, Nursing Department, Tekirdağ; ${ }^{5}$ Osmaniye Korkut Ata University, School of Health, Nursing Department, \\ Osmaniye, Turkey
}

\begin{abstract}
Aim: Complementary and alternative medicine (CAM) usage has increased among the elderly. To promote comprehensive quality care, health professionals should assess for CAM usage. This study was planned to determine the CAM usage among elderly living in nursing homes in Istanbul.
\end{abstract}

Material and Method: This study was made in two nursing homes in Istanbul between December 2012 and May 2013. The study sample consisted of 230 elderly.

Results: A percentage of 59.1 of elderly ( $n=136)$ used CAM. Herbs (55.2\%) and non-herbal supplements (53.5\%) were the most frequently used therapies. CAM usage rate was higher among elderly who graduated from secondary school, had chronic disorder, and used medicine regularly ( $p<0.05$ ); $65.4 \%$ of them did not inform healthcare personnel.

Conclusion: CAM is used commonly by elderly living in nursing homes. Herbal (parsley, garlic and mint) and non-herbal supplements (honey, vitamin B, Vitamin C) were used commonly. Elderly who graduated from secondary school, had chronic disorders, and used medicines regularly preferred using CAM. Elderly generally do not inform healthcare personnel that they have used these methods.

Key words: complementary and alternative medicine; elderly; nursing homes

\section{ÖZET}

Amaç: Tamamlayıcı ve alternatif tıp (TAT) yöntemlerinin kullanımı yașlılar arasında artmıștır. Bakım kalitesini yükseltmek için sağlık profesyonelleri TAT yöntemlerinin kullanımını değerlendirmelidir. Bu çalıșma İstanbul'da iki huzurevinde kalan yașlılarda TAT yöntemlerini kullanma durumunu saptamak amacıyla yapıldı.

Zeynep Erdoğan, Bülent Ecevit Üniversitesi, Abmet Erdoğan Sağllk Hizmetleri Meslek Yüksekokulu, Sağlık Kampüsü, Kozlu, Zonguldak, Türkiye, Tel.03722613348Email.zeynerdogan@hotmail.com Geliş Taribi: 03.02.2016 • Kabul Taribi: 04.03.2017
Materyal ve Metot: Bu çalıșma Aralık 2012 ve Mayıs 2013 tarihleri arasında Istanbul'da iki huzurevinde yapıldı. Çalıșmanın örneklemini 230 yașlı birey olușturdu.

Bulgular: Yașlıların \%59,1'i TAT yöntemlerinden birini kullanıyordu. Bitkiler $(\% 55,2)$ ve bitkisel olmayan destekler $(\% 53,5)$ en çok kullanılan TAT yöntemleriydi. Ortaokul mezunu, kronik bir hastalığı olan ve düzenli tıbbi tedavi alan yașlılar arasında TAT kullanım oranı yüksekti $(p<0,05)$. Yașlıların \%65,4'ü TAT kullandığını sağlık personeline bilgi vermemiști.

Sonuç: Huzurevinde kalan yașlılarda TAT kullanımı yaygındı. Bitkisel (maydanoz, sarımsak ve nane) ve bitkisel olmayan destekler (bal, B ve C vitamini) en yaygın kullanılan yöntemlerdir. Ortaokul mezunu, kronik bir hastalığı olan ve düzenli tıbbi tedavi alan yașlılar TAT kullanımını tercih etmektedir. Yașılar genellikle bu yöntemleri kullandıklarını sağlık personeline söylememektedir.

Anahtar kelimeler: tamamlayıcı ve alternatif tıp; yașlı birey; huzurevi

\section{Introduction}

Complementary and alternative medicine (CAM) is defined by the National Center for Complementary and Alternative Medicine as a group of diverse medical and healthcare systems, practices, and products that are not presently considered to be part of conventional medicine $^{1}$. Although CAM have been used since the time humanity has come into existence, it has started to be used widely after the 90's. In the United States of America, use of CAM increased from $33.8 \%$ to $42.1 \%$ between 1990 and $1997^{2}$. CAM has increased due to factors such as symptoms of a disease, dissatisfaction with health care teams and medical outcomes, high health care charges, side effects of drugs or treatments, lack of control in their own health care practices ${ }^{3-8}$. In a systematic review, prevalence rates of CAM among general population has been 
reported between $5 \%$ and $74.8 \%{ }^{9}$. CAM usage rates may differ between countries or even regions. The usage of CAM varies among cultures according to beliefs, religions, lifestyle, and probably, specific herbs that grow in certain geographical area. CAM usage in Turkey had been subject of some studies. In these studies, the percentage of CAM usage varies between $35.3 \%$ and $86.3 \%{ }^{10-15}$. In studies carried out on elderly individuals, the percentage of CAM usage varies between $27.7 \%$ and $88 \%{ }^{8,16-26}$. These methods have been preferred mostly by elderly who are well-educated ${ }^{3,16,19}$ have a high socio-economical status ${ }^{19,20}$, are female ${ }^{17,19,27,28}$, and are younger elderly ${ }^{16}$. The elderly people have more chronic diseases and disabilities, uses more medications, and often needs more health care services than younger ${ }^{29}$. Rates of chronic diseases are positively associated with CAM usage rates ${ }^{5,16,21}$. As a result, more CAM use can be seen in elderly people in the future. Healthcare professionals'knowledge of the factors which ease or blocks the use of CAM is important in order to protect the health of the elderly population and maintain their safety. In the literature, it has been stated that patients/elderly who used CAM do not inform healthcare personnel, also healthcare personnel do not question CAM usage ${ }^{12,15,18,30}$. Health professionals should assess for CAM use and increase their understanding about the kind and reason of the CAM therapies for comprehensive and qualified care. In addition, it should be assessed whether elderly continue their own medications while using these methods and whether they benefit or get harm from these methods ${ }^{18}$. Although several studies on the determination of CAM methods among the elderly exist ${ }^{16-18,20,21,23,24,26,31}$ there is only a single study carried out in Turkey ${ }^{25}$. Additionally there is not any study on usage of CAM among elderly living in nursing homes. Elderly living in their own houses can be followed by caregivers about medicine and CAM usage. But evaluation of the CAM usage among elderly in nursing homes should be carried out by the nurses regularly. This study was planned to determine the CAM applications and factors associated with its use among elderly people living in nursing homes in Istanbul in Turkey.

\section{Material and Method}

\section{Sample}

This study was made in two nursing homes in Istanbul in Turkey between December 2012 and May 2013. The study was conducted with 230 of the 357 (64.4\%) elderly who living two nursing homes. The patients were aged 65 years and older, had no psychiatric disorder and communication problems and were conscious and consented to participate in the study. Prior to the study, Marmara University Ethics Committee permission was obtained. All elderly were made aware of the proposed study procedures and freely gave written informed consent.

\section{Data Collection Form}

Data was collected by the researchers in a comfortable setting via questionnaire method using the data collection form developed by the researchers. Data collection form included questions on socio-demographic characteristics (age, sex, marital status, educational status, economical status, chronic diseases, regular medication usage, etc.) and CAM usage (CAM types used by elderly, reasons to choose these methods, the benefits and harms of these methods, sources of information for these methods, whether the elderly report using these methods to health professionals). A total of 23 questions were asked and data collection takes approximately 15 minutes.

Data were assessed by using the SPSS 15.0 program (SPSS Inc., Chicago, IL, USA) ${ }^{32}$. In order to analyze the data, means, frequencies, and percentages were calculated. The t-test for independent samples was used to analyze the difference in term of age between patients who use CAM and those who do not. The difference regarding dichotomous and categorical variables between patients who use CAM and those who do not was evaluated with Pearson's chi-square test. The Fisher's exact test was used when the expected value in any box of the chi-square tables containing the dichotomous variables were below 5, and the Pearson's chi-square test was used when all or $80 \%$ of the expected values in any box of the chi-square tables containing the categorical variables were above 5 . A level of significance of $\mathrm{p}<0.05$ was established prior to data collection.

\section{Results}

Mean age of the elderly was $71.86 \pm 6.70$ years. Among 230 elderly, $61.7 \%$ were female and $62.6 \%$ were married. The majority of the elderly graduated from elementary school (44.3\%), more than half of them had social security $(87.4 \%)$, approximately half of them were retired (44.8\%) and $67.8 \%$ had a medium level of income. In this study, $74.8 \%$ had at least one chronic disease, $73.9 \%$ were using medications regularly, $59.1 \%$ were using CAM methods (Table 1).

A percentage of 55.2 of elderly used average $5.13 \pm 3.62$ (min, max: 1,15 ) type herbs/herbal supplements. The 
most frequently used herbs were parsley (32.6\%), garlic (30.9\%), mint (27.8\%), black grape seed (20.9\%), black mulberry (20.4\%), green tea (20.4\%), sage (20.4\%), nettle (18.3\%), and linseed (16.5\%). A percentage of 53.5 of elderly used average $3.15 \pm 2.57$ (min, max: 1 , 11) type non-herbal supplements. The most frequently used non-herbal supplements were honey (31.7\%), vitamin B (23.9\%), Vitamin C (20.4\%), fish oil (19.1\%). Among other CAM methods, the elderly mostly used prayer $(33.9 \%)$, music $(18.3 \%)$, massage $(9.6 \%)$, thermal spring (7\%), and cupping (6.1\%) (Table 2).

A percentage of 69.9 of elderly benefited and a percentage of 0.7 of elderly harmed from the CAM methods they used. Elderly frequently did not tell the healthcare personnel that they have used these methods (65.4\%). The reasons for not telling the

Table 1. Demographic Characteristics of Elderly

\begin{tabular}{|c|c|c|}
\hline Variables & $\mathrm{n}$ & $\%$ \\
\hline Age (years) (mean $\pm S D$ ) & $71.86 \pm 6.7$ & $x: 65,91)$ \\
\hline \multicolumn{3}{|l|}{ Gender } \\
\hline Female & 142 & $61 .^{7}$ \\
\hline Male & 88 & 38.3 \\
\hline \multicolumn{3}{|l|}{ Marital status } \\
\hline Single & 86 & $37 .^{4}$ \\
\hline Married & 144 & 62.6 \\
\hline \multicolumn{3}{|l|}{ Education } \\
\hline Illiterate & 23 & $10 .^{0}$ \\
\hline Literate & 36 & $15 .^{7}$ \\
\hline Elementary school & 102 & $44 .^{3}$ \\
\hline Secondary school & 28 & $12 .^{2}$ \\
\hline High school & 41 & 17.8 \\
\hline \multicolumn{3}{|l|}{ Social security } \\
\hline Yes & 201 & $87 . .^{4}$ \\
\hline No & 29 & 12.6 \\
\hline \multicolumn{3}{|l|}{ Job } \\
\hline Housewife & 97 & $42 .^{2}$ \\
\hline Worker & 11 & $4 .^{8}$ \\
\hline Officer & 3 & $1 .^{3}$ \\
\hline Retired & 103 & $44 .^{8}$ \\
\hline Own business & 16 & 7.0 \\
\hline \multicolumn{3}{|l|}{ Level of income } \\
\hline Poor & 19 & $8 .^{3}$ \\
\hline Moderate & 156 & $67 .^{8}$ \\
\hline Good & 55 & 23.9 \\
\hline \multicolumn{3}{|l|}{ Presence of a chronic disease } \\
\hline Yes & 172 & $74 .^{8}$ \\
\hline No & 58 & 25.2 \\
\hline \multicolumn{3}{|l|}{ Regular drug use } \\
\hline Yes & 170 & $73 .{ }^{9}$ \\
\hline No & 60 & 26.1 \\
\hline \multicolumn{3}{|l|}{ CAM usage } \\
\hline Yes & 136 & $59 .{ }^{1}$ \\
\hline No & 94 & 40.9 \\
\hline
\end{tabular}

CAM, complementary and alternative medicine; SD, standart deviation healthcare personnel were not feeling the need to tell the healthcare personnel (31.6\%), or not being questioned by the healthcare personnel on this subject (30.9\%) and disapproving of these methods (8.1\%). When the reasons for using these methods were

Table 2. The types of CAM used by elderly

\begin{tabular}{|c|c|c|}
\hline & $\mathrm{n}$ & $\%$ \\
\hline Herbs* & 127 & 55.2 \\
\hline Parsley & 75 & 32.6 \\
\hline Garlic & 71 & 30.9 \\
\hline Mint & 64 & 27.8 \\
\hline Thyme & 58 & 25.2 \\
\hline Black grape/seed & 48 & 20.9 \\
\hline Black mulberry & 47 & 20.4 \\
\hline Green tea & 47 & 20.4 \\
\hline Sage & 47 & 20.4 \\
\hline Nettle & 42 & 18.3 \\
\hline Linseed & 38 & 16.5 \\
\hline Black cumin & 28 & 12.2 \\
\hline Radish & 34 & 14.8 \\
\hline Ginger & 24 & 10.4 \\
\hline Cinnamon & 18 & 7.8 \\
\hline Echinacea & 16 & 7 \\
\hline Chicory & 14 & 6.1 \\
\hline Gingko biloba & 2 & 0.9 \\
\hline Ginseng & 2 & 0.9 \\
\hline Non-herbal supplements* & 123 & 53.5 \\
\hline Honey & 73 & 31.7 \\
\hline Vitamin B & 55 & 23.9 \\
\hline Vitamin C & 47 & 20.4 \\
\hline Fish oil & 44 & 19.1 \\
\hline Vitamin D & 35 & 15.2 \\
\hline Vitamin $\mathrm{E}$ & 28 & 12.2 \\
\hline Royal jelly & 27 & 11.7 \\
\hline Vitamin A & 27 & 11.7 \\
\hline Magnesium & 18 & 7.8 \\
\hline Omega 3-6-9 & 17 & 7.4 \\
\hline Coenzyme Q10 & 16 & 7 \\
\hline \multicolumn{3}{|l|}{ Other Therapies* } \\
\hline Prayer & 78 & 33.9 \\
\hline Music & 42 & 18.3 \\
\hline Massage & 22 & 9.6 \\
\hline Thermal spring & 16 & 7 \\
\hline Cupping & 14 & 6.1 \\
\hline Acupuncture & 5 & 2.2 \\
\hline Reflexology & 4 & 1.7 \\
\hline Breathing therapy & 4 & 1.7 \\
\hline Reiki & 3 & 1.3 \\
\hline Yoga & 3 & 1.3 \\
\hline
\end{tabular}

CAM, complementary and alternative medicine. *More than one option was selected. 
asked; the participants stated more than one reason. Elderly used these methods because these methods made them feel better $(80.1 \%)$, they thought these methods were beneficial (60.3\%), these methods increased immunity (32.4\%), they thought these methods support medical treatments $(22.8 \%)$, had less side effects (18.4\%), they did not benefit from medical treatment $(17.6 \%)$, these methods were cheaper $(8.8 \%)$ and they did not have another option (5.9\%). A percentage of 64.7 of the elderly have heard of these methods from friends and family, the media (32.4\%), healthcare personnel (25\%), pharmacies $(8.1 \%)$, and the internet $(6.6 \%)$ (Table 3 ).

There were a statistically significant differences between elderly who use and who do not use CAM methods regarding education level $(p=0.016)$, presence of a chronic disease $(p=0.011)$ and regular drug use $(p$ $=0.004)$. CAM usage rate was higher among elderly who graduated from secondary school, had chronic disorders, and used medicines regularly. On the other hand, there were no statistically significant differences between elderly who use and who do not use CAM methods regarding age, gender, marital status, social security, job, level of income ( $p>0.05)$ (Table 4).

\section{Discussion}

Comorbid conditions which increase with age, the elderly's wish to increase the quality of life and manage chronic problems leads them to be in search of CAM ${ }^{8}$. CAM methods used by elderly might vary according to geographical areas and culture. Health care providers must be aware that elderly are using CAM and are satisfied with their use ${ }^{8,33}$. Elderly may benefit from some CAM methods but during some CAM methods usage, undesired and even life-threatening side effects may occur. Health professionals play an important role in defining these side effects in early phases, and take precautions. Therefore, health professionals should question elderly on CAM usage ${ }^{34}$.

\section{The Frequency of CAM Usage}

In this study, more than half of the elderly (59.1\%) used at least one of the CAM methods. In studies carried out on elderly about CAM usage, CAM usage rates vary between $27.7 \%$ and $88 \% \%^{8,16-26}$. Because different CAM methods have been investigated in studies, different results on the frequency of CAM usage might have been obtained. Findings of this study are parallel to the literature.
Table 3. Characteristics related to CAM usage $(n=136)$

\begin{tabular}{|c|c|c|}
\hline & $\mathrm{n}$ & $\%$ \\
\hline \multicolumn{3}{|l|}{ State of benefiting from CAM usage } \\
\hline Yes & 95 & 69.9 \\
\hline Partially & 28 & 20.5 \\
\hline No & 13 & 9.6 \\
\hline \multicolumn{3}{|l|}{ State of harming from CAM usage } \\
\hline Yes & 1 & 0.7 \\
\hline No & 134 & 98.5 \\
\hline Partially & 1 & 0.7 \\
\hline \multicolumn{3}{|c|}{ Healthcare personnel's state of being aware of CAM usage } \\
\hline Yes & 47 & 34.6 \\
\hline No & 89 & 65.4 \\
\hline \multicolumn{3}{|l|}{ The reasons of healthcare personnel's unawareness* } \\
\hline I did not feel the need to tell & 43 & 31.6 \\
\hline $\begin{array}{l}\text { The healthcare personnel does not ask } \\
\text { questions }\end{array}$ & 42 & 30.9 \\
\hline The healthcare personnel will disapprove & 11 & 8.1 \\
\hline $\begin{array}{l}\text { The healthcare personnel is not } \\
\text { knowledgeable about CAM }\end{array}$ & 8 & 5.9 \\
\hline The time of healthcare personnel is limited & 5 & 3.7 \\
\hline \multicolumn{3}{|l|}{ Reasons for CAM usage* } \\
\hline It makes me feel better & 109 & 80.1 \\
\hline I think it is beneficial & 82 & 60.3 \\
\hline It increases my body defense/immunity & 44 & 32.4 \\
\hline Support to my medical treatment & 31 & 22.8 \\
\hline It has less side effects & 25 & 18.4 \\
\hline I do not benefit from my medical treatment & 24 & 17.6 \\
\hline It is cheaper than medical treatment & 12 & 8.8 \\
\hline I do not have any other option & 8 & 5.9 \\
\hline \multicolumn{3}{|l|}{ Sources of information on $\mathrm{CAM}^{*}$} \\
\hline Friends-family & 88 & 64.7 \\
\hline Media-TV & 44 & 32.4 \\
\hline Healthcare personnel & 34 & 25 \\
\hline Pharmacy & 11 & 8.1 \\
\hline Internet & 9 & 6.6 \\
\hline Books/magazines & 8 & 5.9 \\
\hline
\end{tabular}

CAM, complementary and alternative medicine. ${ }^{*}$ More than one option was selected.

\section{CAM Methods Used by Elderly}

The most preferred CAM type in this study was herbs. A percentage of 55.2 of elderly used average $5.13 \pm 3.62$ (min, max: 1, 15) type herbs/herbal supplements. In parallel to this findings, Astin et al. ${ }^{16}$ and Loera et al. ${ }^{23}$ found that herbs are the most common CAM type used by the elderly. Among CAM methods, the use of herbs has increased in the last two decades. ${ }^{35}$ In general; elderly people believe that herbs are safe, side effect free, and non-addictive. Because herbs are assumed to be natural and safe, they are sold in many markets and stores, are easily accessed and do not need to be prescribed ${ }^{36}$. 
Table 4. Factors associated with CAM usage $(n=230)$

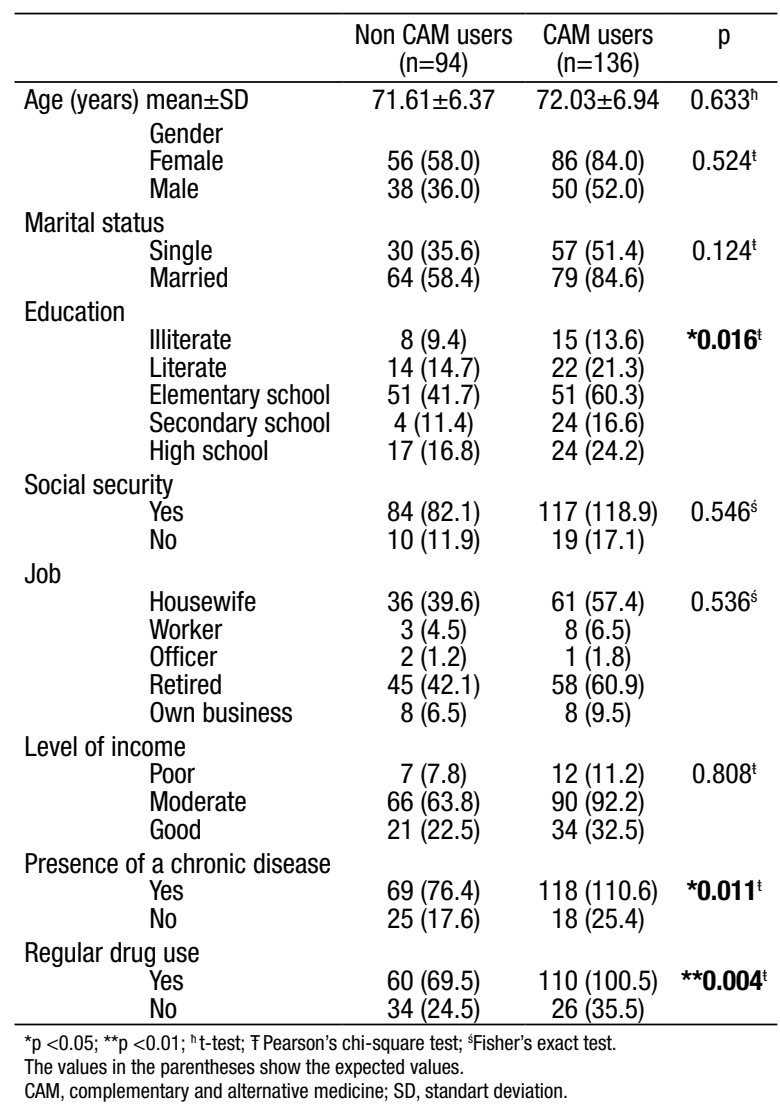

In this study, the most preferred herbs by the elderly are parsley, garlic, mint, thyme, black grape seed, black mulberry, green tea, sage, nettle, and linseed; respectively. It has been reported that chamomile, heliotrope and other herbal teas including licorice, hibiscus, vervain, linden ${ }^{17}$, garlic $^{16,20}$, echinace ${ }^{18}$, gingkgo ${ }^{16,20}$, ginseng ${ }^{16,20}$ and phytotherapeutic products ${ }^{27}$ are commonly consumed by the elderly. Consistent with the literature, in this study, herbs have been preferred primarily; however, the herb kinds that the elderly use in our study are different. The reason for this may be related to the variety of herbs that exist in a specific region and certain geographical and climate conditions.

In this study, herbs and non-herbal supplements were used frequently by elderly (including multivitamins). A percentage of 53.5 of elderly used at least one type non-herbal supplements. Mean non-herbal supplement number/type used by elderly were $3.15 \pm 2.57$. The use of dietary supplements such as vitamins and multivitamins are increasing around the world. In the USA, approximately half of the adult population regularly consumes one or more dietary supplements ${ }^{37}$. In this study, we have observed that the elderly have used non-herbal supplements such as honey, vitamins (vitamin B, vitamin C, vitamin $\mathrm{D}$, vitamin $\mathrm{E}$, and vitamin A; respectively), fish oil, royal jelly, magnesium, omega 3-6-9, and coenzyme Q10 at rates differing between $7 \%$ and $31.7 \%$. Previous studies showed that elderly individuals mostly use vitamin $\mathrm{E}^{18,20}, \mathrm{Ca}^{20,26}$, magnesium ${ }^{26}$, iron ${ }^{26}$, vitamin $\mathrm{C}^{18,20}$, vitamin $\mathrm{D}_{3}^{26}, \mathrm{~B}_{12}{ }^{26}$, folic acid ${ }^{26}$, chondroitin sulphate ${ }^{18}$ and minerals ${ }^{18}$. Our study results are in line with the literature.

When we examined other CAM types, we found that the elderly mainly used prayer (33.9\%), which was followed by music (18.3\%), massage (9.6\%), and thermal springs (7\%); respectively. When we examined the literature, other mainly used CAM types included prayer ${ }^{31}$, spiritual practices ${ }^{19}$, massage $e^{8,20,31}$, exercise/movement therapies ${ }^{19}$, special diets ${ }^{19}$, chiropractice ${ }^{8,19,24}$, meditation $^{19,20,24,31}$ and breathing exercises ${ }^{20}$. The reason that praying was the most preferred method in this study is thought to originate from the fact that elderly people resort to religious practices in terms of solving health problems in Turkey, where the majority of the population is Muslim. In this study, we have observed that applications such as breathing exercises, meditation, chiropractice, acupuncture, hypnosis, yoga and energy therapies are rarely or never used. The reason for this may be CAM practitioners not being common in Turkey and Turkish elderly not being informed about these methods.

\section{Informing Health Professionals about CAM Usage}

In this study, although most of the (69.9\%) of the elderly who used CAM methods have told that they benefited from these methods, it was found that $65.4 \%$ of them did not inform healthcare personnel.

The elderly reported that the reasons for not telling included not feeling the need to tell (31.6\%), or not being questioned by the healthcare personnel about CAM usage (30.9\%) and not approving such usage (8.1\%). Also, in previous studies, it was found that the elderly substantially benefited from CAM methods and that they did not tell the healthcare personnel about these methods at varying rates of $47 \%$ and $58 \%{ }^{8,16}$. The reasons for this include 'not being asked by healthcare personnel on the subject, the participants not knowing that they should have told they used these methods and thinking that it is not important for their care's. Our research findings are in parallel with these results. In summary, the elderly being afraid to share information with the healthcare personnel about the usage of CAM methods causes a weak 
communication between the elderly and the healthcare personnel. Unless the obstacles related to information sharing are noticed and an open communication is provided, the elderly and the healthcare personnel will be less aware of the interaction between traditional medical treatments and CAM methods ${ }^{16}$.

\section{The Reasons for CAM Usage}

It was found that the elderly use these methods because they felt good (80.1\%), CAM are beneficial (60.3\%), CAM increased body defense/immunity (32.4\%), they did not benefit from medical treatment (17\%), CAM supported to medical treatment (22.8\%), and CAM's side effects were fewer compared to traditional medical treatments (18.4\%). In the literature, the elderly people reported that they used CAM methods due to reasons similar to those found in our study, such as being dissatisfied with traditional medical treatment ${ }^{16}$, fearing medication side effects $^{16}$, improving the general state of health ${ }^{8,16}$, treating health problems ${ }^{8}$ and staying healthy ${ }^{31}$.

\section{Sources of Information}

When we examined how the elderly reached sources of information on these methods, it was determined that $64.7 \%$ of the participants have heard of these methods from friends and family, the media (32.4\%), healthcare personnel (25\%), pharmacies (8.1\%), and the internet (6.6\%). Schnabel et al. ${ }^{26}$ and King and Pettigrew ${ }^{31}$ also stated that elderly individuals used these methods because they were advised to do so by friends-family, doctors, pharmacists, medical or nonmedical practitioners, and the TV-radio or they chose to do so on their own. Many patients emphasize that they want to get involved in the diagnosis, planning and caring processes regarding their illness. In order to do this, they receive information through various sources. During the process of decision making about health care, open communication should be established and judgmentalism should be avoided in order to ease the patient's acquisition of correct and reliable information. In every stage of treatment, healthcare personnel should evaluate the options with patients before providing traditional medical treatment so that they can prevent insensible and secret use of CAM methods ${ }^{38}$.

\section{Factors Associated with CAM Usage}

In this study there were statistically significant differences between elderly who use and who do not use CAM methods in terms of education level; secondary school graduates were using CAM more. Similar to this study's results, it has been reported that CAM usage is more common among people with higher levels of education ${ }^{16,19,21}$.

In this study, the majority of the elderly individuals had one chronic disease (74.8\%) and CAM usage was more common among elderly individuals who had a chronic disease and who used medications regularly. Elderly individuals use an increasing amount of medication due to chronic health problems that increase during old age. Thus, this condition increases both the morbidity and mortality risks related to medication side effects ${ }^{39}$. Elderly individuals tend towards CAM methods due to both physiological factors such as chronic diseases and unwanted situations caused by multiple medications use $\mathrm{e}^{16,20,8}$. Results of relevant studies support our findings. In previous studies, it has been reported that CAM usage is more common among people who have multiple health problems ${ }^{21,23}$ those who suffer from health problems such as chronic pain $^{8}$, arthritis ${ }^{8,16}$ and depression/anxiety ${ }^{16}$ and those practice medication ${ }^{16}$.

In this study, there were no statistically significant differences between elderly who use and who do not use CAM methods regarding age, gender, marital status, social security, job, level of income. Cheung et al. ${ }^{8}$ found that there is no relationship between socio-demographic characteristics such as age, gender, marital status and income level and CAM usage. Cheung et al.'s results are parallel to this study results. But other studies that evaluate CAM usage according to sociodemographic characteristics among the elderly, it was reported that females ${ }^{17,19,21,23}$, young elderly ${ }^{16,21}$, unmarried ${ }^{23}$ and high income level ${ }^{19} \mathrm{CAM}$ methods were more frequently used.

CAM is used commonly by elderly people living in nursing homes in Istanbul in Turkey. Herbal supplements (parsley, garlic and mint) and non-herbal supplements (honey, vitamin B, Vitamin C) were used commonly. Elderly generally do not inform healthcare personnel that they have used these methods. Most of the elderly who used CAM methods benefit from these methods without getting any harm. The rate of CAM usage is higher among elderly who graduate from secondary school, have chronic disorders, and use medicine regularly.

\section{References}

1. National Center for Complementary and Integrative Health. Complementary, Alternative, or Integrative Health: What's in a Name? Available from URL. https://nccih.nih.gov/health/ integrative-health Accessed 15 November 2015. 
2. Eisenberg DM, Davis RB, Ettner SL, Appel S, Wilkey S, Rompay MV, Kessler RC. Trends in Alternative Medicine Use in the United States, 1990-1997 Results of a Follow-up National Survey. JAMA 1998;280:1569-1575.

3. Astin J. Why patients use alternative medicine: results of a national study. JAMA 1998; 279:1548-1553.

4. Shua-Haim J, Ross J. Alternative medicine in geriatrics: competing with or complementing conventional medicine? Clin Geriatr $1999 ; 7$.

5. Willison K, Andrews G. Complementary medicine and older people: past research and future directions. Complementary Therapies in Nursing \& Midwifery 2004;10:80-91.

6. Erdogan Z, Cinar S. Reiki: An Ancient Healing Art - Modern Nursing Practice. Kafkas J Med Sci 2011;1:86-91.

7. Snyder M, Lindquist R. Issues in complementary therapies: how we got to where we are. J Issues Nurs 2001;6:1.

8. Cheung C, Wyman J, Halcon L. Use of complementary and alternative therapies in community-dwelling older adults. J Alternative Complementary Med 2007;13:997-1006.

9. Frass M, Strass, RP, Friehs H, Müllner M, Kundi M, Kaye AD. Use and acceptance of complementary and alternative medicine among the general population and medical personnel: A systematic review. Ochsner J 2012;12: 45-56.

10. Tas F, Ustuner Z, Can G, Eralp Y, Camlica H, Basaran M, Karagol H, Sakar B, Disci, R, Topuz E. The prevalence and determinants of the use of complementary and alternative medicine in adult Turkish cancerpatients. Acta Oncol 2005;44:161-167.

11. Tarhan O, Alacacioglu A, Somali I, Sipahi H, Zencir M, Oztop I, Dirioz M, Yilmaz U. Complementary-alternative medicine among cancer patients in the western region of Turkey. J Balkan Union Oncol 2009; 14:265-269.

12. Akinci AC, Zengin N, Yildiz H, Sener E, Gunaydin B. The complementary and alternative medicine use among asthma and chronic obstructive pulmonary disease patients in the southern region of Turkey. Inter J Nurs Practice 2011;17:571-582.

13. Erdogan Z, Oguz S, Erol E. Use of complementary therapies in the patients with heart disease. Spatula DD 2012;2:135-139.

14. Kucukoner M, Bilge Z, Isıkdogan A, Kaplan MA, Inal A, Urakci Z. Complementary and alternative medicine usage in cancer patients in southeast of Turkey. AJTCAM 2012;10:1-5.

15. Erdogan Z, Cinar S, Simsek S. The relationship between hopelessness level and the use of complementary medicine methods in hemodialysis patients. Spatula DD 2013;3:107-112.

16. Astin J, Pelletier K, Marie A, Haskell W. Complementary and alternative medicine use among elderly persons: one-year analysis of a blue shield medicare supplement. J Gerontol Series A. Biol Sci Med Sci 2000;55:4-9.

17. Buono MD, Urciuoli O, Marietta P, Padoani W, De Leo D. Alternative medicine in a sample of 655 community-dwelling elderly. J Psychosomatic Res 2001;50:147-154.

18. Cohen RJ, Ek K, Pan CX. Complementary and alternative medicine (CAM) use by older adults: a comparison of self-report and physician chart documentation. J Gerontol Series A. Biol Sci Med Sci 2002;57:223-227.

19. McMahan S, Lutz R. Alternative therapy use among the young-old (ages 65 to 74): An evaluation of the MIDUS Database. J Applied Gerontol 2004;23:91-103.

20. Ness J, Cirillo DJ, Weir DR, Nisly NL, Wallace R. Use of complementary medicine in older Americans: results from the health and retirement study. Gerontologist 2005, 45:516-524.
21. Arcury TA, Suerken CK, Grzywacz JG, Bell RA, Lang W, Quandt SA Complementary and alternative medicine use among older adults: ethnic variation. Ethnicity \& Disease 2006;16:723-731.

22. Grzywacz J, Suerken C, Quandt S, Bell R, Lang W, Arcury TA. Older adults' use of complementary and alternative medicine for mental health: findings from the 2002 National health interview survey. J Alternative Complementary Med 2006;12:467-473.

23. Loera JA, Ortizb CR, Kuoa YF. Predictors of complementary and alternative medicine use among older Mexican Americans. Comp Therapies Clin Pract 2007;13:224-231.

24. Zhang AL, Xue CC, Lin V, Story DF. Complementary and alternative medicine use by older Australians. Ann New York Academy Sci 2007;1114:204-215.

25. Dedeli O, Karadakovan A. Investigation of complementary and alternative medicine practice and drug use in the elderly. Spatula DD 2011;1:23-32.

26. Schnabel K, Binting S, Witt CM, Teut M. Use of complementary and alternative medicine by older adults - a cross-sectional survey. BMC Geriatr 2014;14:1-9.

27. Raji MA, Kuo YF, Snih SA, Sharaf BM, Loera JA. Ethnic differences in herb and vitamin/mineral use in the elderly. Ann Pharmacotherapy 2005;39:1019-1023.

28. Büssing A, Ostermann T, Heusser P, Matthiessen PF. Usage of alternative medical systems, acupuncture, homeopathy and anthroposophic medicine, by older German adults. Zhong Xi Yi Jie He Xue Bao 2011;9:847-856.

29. World Health Organization. The World report on ageing and health. Available from URL. http://www.who.int/ageing/events/ world-report-2015-launch/en. Accessed 15 November 2015.

30. Najm W, Reinsch S, Hoehler F, Tobis J. Use of complementary and alternative medicine among the ethnic elderly. Alternative Therap Health Med 2003;9:50-57.

31. King MOB, Pettigrew AC. Complementary and alternative therapy use by older adults in three ethnically diverse populations: a pilot study. Geriatric Nurs 2004;25:30-37.

32. SPSS Inc. SPSS for Windows-Release 15. Chicago: SPSS Inc, 2008.

33. Cuellar N, Aycock T, Cahill B, Ford J. Complementary and alternative medicine (CAM) use by african american (AA) and caucasian american (CA) older adults in a rural setting: a descriptive, comparative study. BMC Comp Alternative Med 2003;3:8.

34. Helms JE. Complementary and alternative therapies: A new frontier for nursing education? J Nurs Education 2006;45:117123.

35. Cassileth B, Heitzer M, Gubili, J. Integrative oncology: Complementary therapies in cancer care. Cancer Chemotherapy Rev 2008;3:204-211.

36. Stuart AG. Herbal product use by older adults. Maturitas 2011:68:52-55.

37. Gahche J, Bailey R, Burt V, Hughes J, Yetley E, Dwyer J, Picciano MF, McDowell M, Sempos C. Dietary supplement use among U. S. adults has increased since NHANES III(1988-1994). NCHS Data Brief 2011;61:1-8.

38. Davis EL, Oh B, Butow PN, Mullan B, Clarke S. Cancer patient disclosure and patient-doctor communication of complementary and alternative medicine use: a systematic review. Oncologist 2012;17:1475-1481.

39. Kutsal YG. Polypharmacy in elderly. Tr Geriatr 2006;(special issue):37-44. 